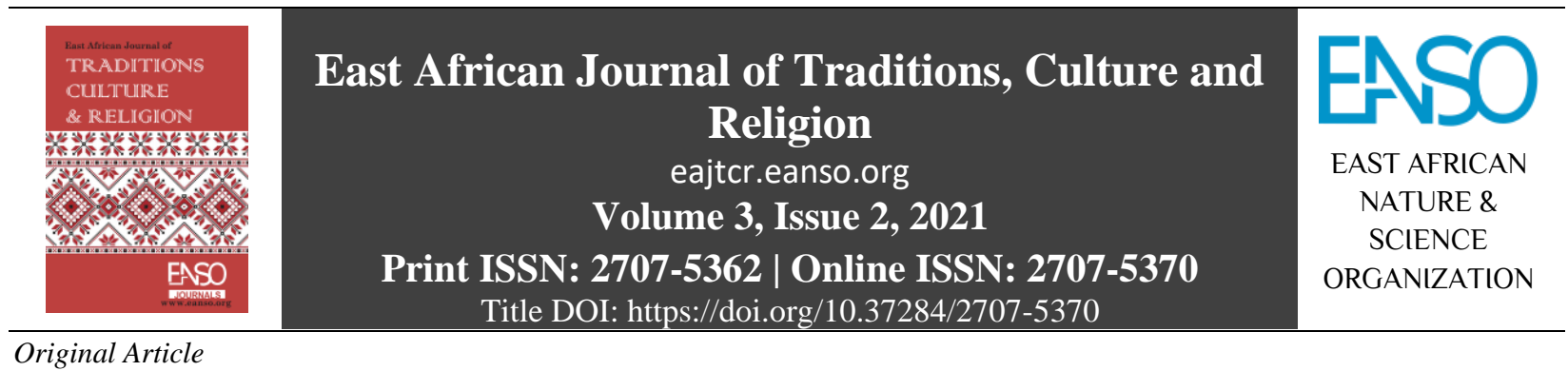

\title{
Deconstruction as a Functional Tool in Decolonizing Nigerian Educational System: A Biblical Response.
}

\author{
Dr. Osbert Uyovwieyovwe Isiorhovoja, PhD \\ ${ }^{1}$ Department of Religious Studies and Philosophy, Delta State University, P.M.B. 1, Abraka Nigeria. \\ Author Correspondence Email: evanosbert@gmail.com.
}

Article DOI: https://doi.org/10.37284/eajtcr.3.1.426

\section{Date Published: ABSTRACT}

04 October 2021 The paper examines the role of deconstruction in the Nigerian educational system vis-à-vis its functionality to the growing needs and challenges be

Keywords: devilling the nation. Arguably, the content of the system has been commonly viewed sometimes as dysfunctional, tilted toward the needs of the colonial

Deconstruction, agenda. This phenomenon did only leave the endeavour handicapped but also

Decolonization,

Functional, totally reliant on foreign ideology; a system that estranged the people. The paper adopts hermeneutical, historical, and critical approaches to the phenomenon. Biblical Response, From a biblical perspective, while searching for relevance, there has been the Curriculum. need to decolonize certain aspects which otherwise have alienated the people, with the aim of targeting functionality and acceptability among Africans. The need to contextualize a foreign curriculum that will bring about a total overhauling of the system to achieve a vibrant curriculum remains a necessity in order to service the needs of the people. As in the decolonisation exercise among biblical scholars, chances are that we can achieve a great feat in our nation's education sector. It concludes by resounding that the present educational system is deconstructed with the aim of removing dysfunctional elements; with full integration of a rich indigenous knowledge base that serves the people's uniqueness amidst conflicting curriculum, the government should be proud to introduce into the educational system a fresh idea that meets the needs as posited by biblical scholars.

\section{APA CITATION}

Isiorhovoja, O. U. (2021). Deconstruction as a Functional Tool in Decolonizing Nigerian Educational System: A Biblical Response. East African Journal of Traditions, Culture and Religion, 3(1), 79-89. https://doi.org/10.37284/eajtcr.3.2.426

\section{CHICAGO CITATION}

Isiorhovoja, Osbert Uyovwieyovwe. 2021. "Deconstruction as a Functional Tool in Decolonizing Nigerian Educational System: A Biblical Response". East African Journal of Traditions, Culture and Religion 3 (2), 79-89. https://doi.org/10.37284/eajtcr.3.2. 426.

79 | This work is licensed under a Creative Commons Attribution 4.0 International License. 


\section{HARVARD CITATION}

Isiorhovoja, O. U. (2021) "Deconstruction as a Functional Tool in Decolonizing Nigerian Educational System: A Biblical Response.”, East African Journal of Traditions, Culture and Religion, 3(1), pp. 79-89. doi: 10.37284/eajtcr 3.2. 426.

\section{IEEE CITATION}

O. U. Isiorhovoja, "Deconstruction as a Functional Tool in Decolonizing Nigerian Educational System: A Biblical Response.", EAJTCR, vol. 3, no. 2, pp. 79-89 Oct. 2021.

\section{MLA CITATION}

Isiorhovoja, Osbert Uyovwieyovwe. "Deconstruction as a Functional Tool in Decolonizing Nigerian Educational System: A Biblical Response." East African Journal of Traditions, Culture and Religion, Vol. 3, no. 1, Oct. 2021, pp. 79-89, doi:10.37284/eajtcr.3.2.426.

\section{INTRODUCTION}

The quest for the decolonisation of biblical studies has been the task of Africans both at home and in the diaspora. It, however, took a gradual global trend when scholars like Prof. D. T. Adamo, Justin Ukpong, and Surjitharajah among others played some lead roles by responding to the 'Eurocentric' biblical interpretation by presenting the African Cultural Hermeneutics as a response and platform for African voice.

Adamo (2005) argues that the need for decolonization did not stem from the desire to understand the written text but to encounter God within the local culture of the people. The need to read and feel at home with the text and some important African personalities whose roles at various times have contributed to the development of the Israel nation and indeed the ancient world. In the biblical period, the beauty of the exercise lies in the noble roles and positions occupied in the life of the nation of Israel as well as identification with African and Africans both as a people and a place. The efforts also seek to end the hermeneutical hegemony tilted towards Eurocentric biblical interpretation that alienated Africans and their rich culture from serving as the basis of biblical interpretation in Nigeria and indeed Africa.

Wahab et al. (2012) attest to the inseparable nature of culture from Africans. This they define to include the way of life of any group of persons. This is a known fact among Africans as they practice a live culture that daily serves as the basis of interaction and understanding of reality. Mbiti (1956) once note that Africans are unique as they carry not only carry their God wherever they go but practice and sustain the rich cultural heritage. Thus, it serves as a major determinant for the interpretation of the day-to-day live experiences of the people. Hence it formed the hub of traditional knowledge system and learning. Also, socio-cultural activities and related issues are addressed from this dimension.

Adamo (2005) posits that the goal of decolonization is not to cause any known form of uproar but to critically appraise the status-quo of the ancient biblical tradition in the light of African worldview, culture, and life experiences that seeks to explore African understanding as a method of interpretation. Since there is no cultural vacuum, biblical interpretation within the African socio-cultural context remained the goal of decolonization through effective African Cultural hermeneutics.

The pursuance of this process like other third-world countries explores the liberation approach. Cone (1970) contends that there is no theological vacuum for theology in time-bound as well as a definite location with a cultural context. Hence the lob-sided approach to Christian theology that is void of liberation should be classified as oppressive and anti-human; counterproductive and gospel.

Adamo (1999) in qualifying the quality and characteristics of African cultural hermeneutics argues that its postmodern in nature, liberation, and culturally sensitive to the needs of the people hence, imagination, oral traditions, oral narratives, and folklore and tools are employed in response to colonization of the indigenous people. He further buttressed Cone (1970), who addressed the impossibilities of theological vacuum in the task of theological interpretation.

\section{Systematic Colonization of African Faith}

The coming of the gospel to the black continent was presented without an iota of African input to the overall alienation of the people. Western scholarship tried the much they could to erase the 
presence of the continent. Dakes (1963) presented the annotated maps of the Ancient World with Egypt being part of Europe. Such representation did not only portray a shallow knowledge of the biblical world but an outright distortion of the biblical content. While Western scholars are of the opinion that Prof. D.T. Adamo tried to smuggle Africa into the Bible, the converse is actually the case. Western scholars have tried to delete African presence away from the Bible. The Maps below further buttress the argument of African presence being smuggled away from the Bible and the Ancient World. Fig. A shows the right presentation with the Nile. While Fig. B shows the smuggling of Africa away from the Ancient World.

\section{Figure 1: Africa fully represented in the Map in the Dark shaded region (Fertile Crescent)}

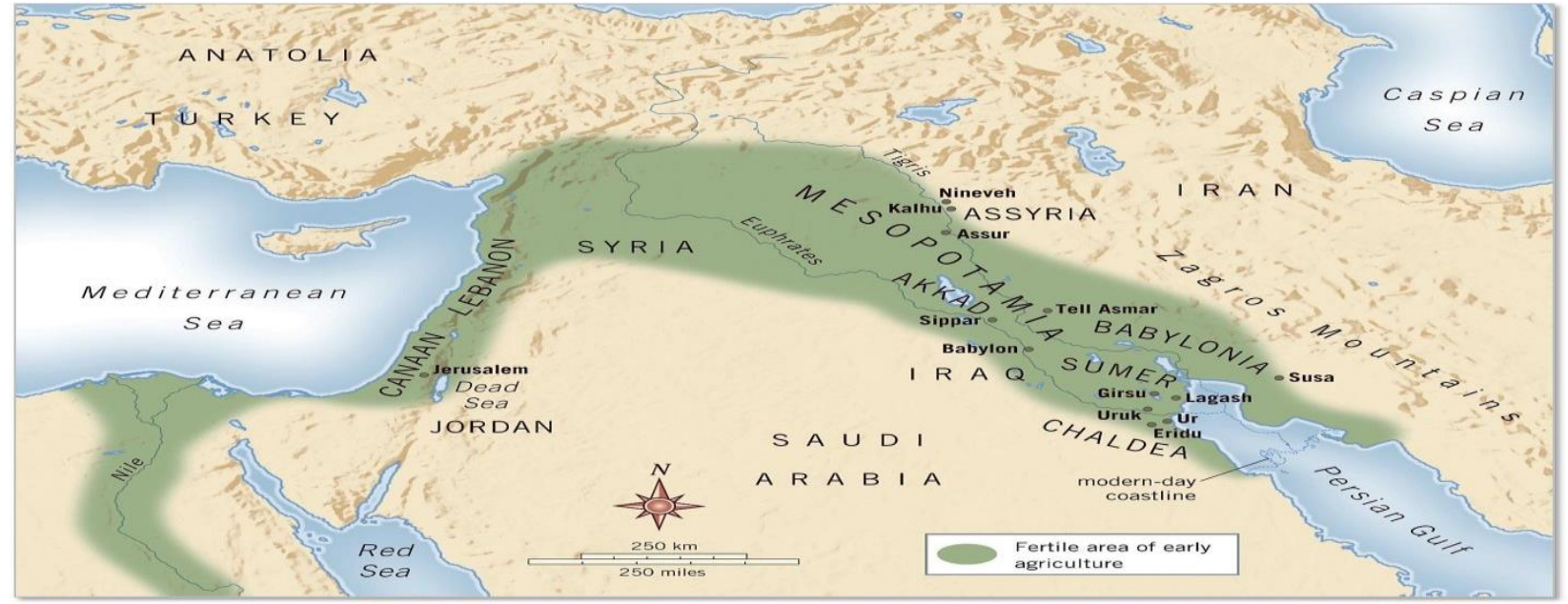

Figure 2: Africa already smuggled out of the Ancient World

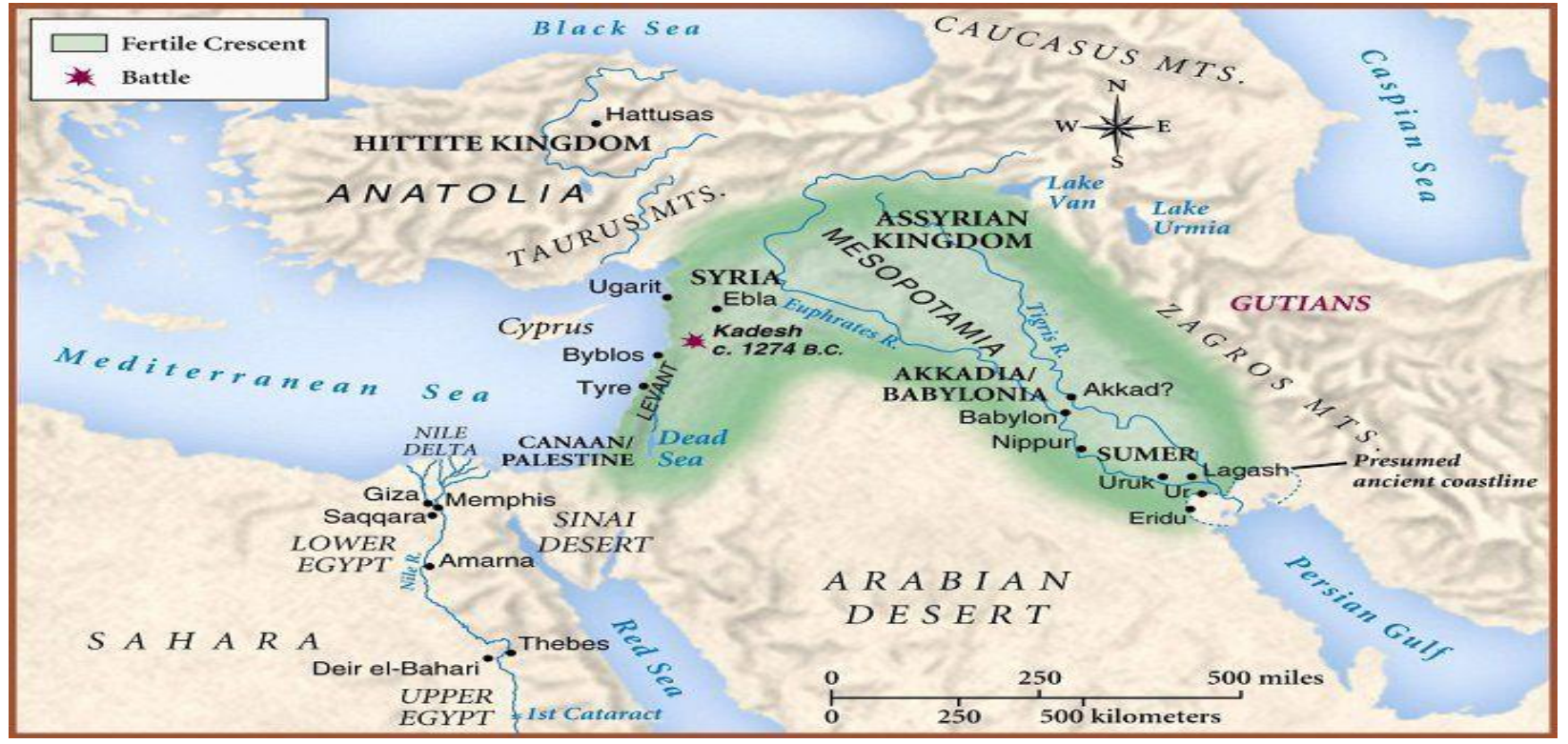

The African military men in King David's army 2nd Samuel 18-21-

32.

The era of the united monarchy was bedevilled with the crisis. Examples include the crisis between Saul and Samuel, David and Sheba, jeroboam and
Rehoboam. King Solomon's oppressive policies also contributed to the crisis of the era, the bane of the problem rest on the oppressive policies of King Solomon who has tension from the tribes due to independence and jealousy. This did not escape the

81 This work is licensed under a Creative Commons Attribution 4.0 International License. 
monarchy even though there was brilliant in the performance of both David and Solomon, the presence of an unnamed African man in King David's army meant a whole lot of difference in his struggle with Absalom. This Cushites' identity has been contested by some Western scholars that an African could not have attained such a noble rank under King David; they wish to smuggle him away if not for his Cushitic skin colour.

Gavin (2011) corroborates Adamo (1986, 2005) on the status of Cushites, Kush, and Kushi. Both scholars identified Africans as a location in name and the people however in the book of Jeremiah Western scholars still dispute the name kush Edison location weed in Africa or Mesopotamia. This is why the dimension of Kush or Egypt in biblical literature refers to the same people and place other names that are used in the representation of Africa as a text to the region a geographical location for the people with dark coloured skin.

Lokel (2006) motioned that the quest for Africa and Africans in the Old Testament is new yet fast gaining wider acceptability as the text borders on Kush. He argues that it is essential to establish the geography through biblical maps that reveal the location of Kush. This task he undertook by drawing attention to the underrepresentation as evidenced in the biblical texts, Bible Dictionaries, Commentaries, Concordances, and Lexicons.

Gottwald ((1985) in his acclaimed work on the Hebrew Bible, mentioned Egypt among other important cities that flourished in ancient times especially along the rivers. He however did not make a specific reference to Kush especially in relation to being the father of Prophet Zephaniah, who is the great-grandson of King Hezekiah. The reference here to Kush is passive, a vague application to a region around the Nile, south of Egypt. This tendency to ignore Kush is best interpreted as smuggling away of Africa from the Bible especially, reference to Bible lands in biblical maps limits the continent to Egypt alone or sometimes locate Kush or ancient Ethiopia outside the continent while depicting the exact location of the Garden of Eden. Bailey (1991) points out that the cartographer W. R. Annim located Africa in Persia as the land of Kush. This misrepresentation was again demonstrated by Joseph Irwin Wilson who also failed to mention the account in Genesis 2: 10-14 with the land of Kush in his mention of the Rivers of Eden.

Crim et al (1982) in his supplementary volume of the Interpreter's Dictionary of the Bible actually located Kush either in Africa or in the Arabian Peninsula, making the location looks ambiguous. Bromiley (1979) from the International Standard Bible Encyclopaedia shows that Kush is in Africa and associated with Nubia or Ethiopia or rather in Mesopotamia among the Kassites. Achtemeier (1996) in Harpercollins Bible Dictionary almost throughout place Egypt in Near Eastern land and not with the rest of Africa. These Western scholars have made efforts to smuggle Africa out of the Bible, systematic mental decolonisation of the younger generation of African and African in diaspora hence the challenges of deconstruction of all works otherwise not portraying the continent rightly.

\section{Need for Biblical Decolonization}

The quest for the decolonisation of biblical studies has been the task of Africans both at home and in the diaspora. It, however, took a gradual global trend when scholars like Prof. D. T. Adamo, Justin Ukpong and Surjitharajah among others responded to 'Eurocentric' biblical interpretation through African Cultural Hermeneutics as a platform for African voice to be heard and recognised.

Adamo (2005) argues that the need for decolonization stems from the desire to understand the written text and to encounter God within the local context. Lokel (2006) adds that the essence should also include prioritizing the place as a definite location and the persons who are of African origin, irrespective of the continent where they are found and living in presently.

Heinrichs (2000) notes that biblical decolonization has drawn both negative and positive attention. In his work, "Unsettling the Word: Biblical Experiments in Decolonization", that addressed the role of the Bible in the history of civilization as used by colonialists and they need to rescue the scriptures from what he called "principalities and powers" $\mathrm{He}$ notes that the Bible has been abused and subjected to a mono interpretation, a reading from a master to a slave. Thus, the need to wrestle with scriptures as to arrive at the deeper metaphorical meaning to the 
use of social-cultural context in the interpretation of the text.

This approach addresses the felt need among the people to bring liberation to the oppressed. Such interpretation is not easy, is bedevilled with challenges especially from the colonizers who primarily use the Bible as a tool for oppression and to enforce master-slave loyalty in the society. This phenomenon he captioned, arguing that there should be a clarion call for reinterpretation aimed at valiantly revisiting the Bible as to get relief from the hands of the oppressors who have used it as a tool of oppression against the people. Once this is done, there will be a great sigh of relief because the socialcultural context of the people should inform the basis for interpretation, the thesis of black liberation theology as espoused by Africans.

The need to read and feel at home with the text and some important African personalities whose roles have been benighted in the Bible remained the hue and cry of most African scholars from all disciplines of life. Adamo (2006) vehemently challenged biblical and other disciplines that would rather promote racism, silencing a whole race or people through conscious effort, attempts to de-Africanise the continent through neo-colonialism, alienating the people and destroying their heritage intentionally.

From the formation of the New Testament, it is quite obvious that Africans played major roles in the canonicity which is the hallmark of the selection of the Books of the New Testament. Some important personalities worthy of note here include Pantaenus, Clement of Alexandria, Origen, Tertullian and Cyprian of Carthage. These are notable men of African origin whose background may have been stolen away or couched under western background.

The non-recognition of the continent with the various appellations from antiquity shows that the reference to the continent has been greatly suppressed under western scholarship. In Acts 8:2628, the account of the African Minister of Finance otherwise referred to as 'eunuch' in the NIV version is rather misleading about his person and identity of this African; a devout man, treasurer and Theophilus, a well-respected personality who has made it a point of duty to always go to Jerusalem for worship. Since the western emphasis is tailored towards defaming and denting his image, African scholars have not failed in raising some thoughts about this man. Pertinent among them is the state of the man financially. Can a poor man embark on such a journey from the land of Cush (Ethiopia) to Jerusalem? Do slaves ride on the cart and be granted religious freedom and autonomy? Are there marks that portray the man as a servant? All these run contrary to the definition of a eunuch, a male servant in the service of the Queen. Hence, the denied interpretation is that the man was the Minister of Finance with reputation. (Adamo, 2006)

To end the hermeneutical hegemony tilted towards Eurocentric biblical interpretation that alienated our rich African culture from serving as the basis of biblical interpretation. Cone (1970) argues in favour of the plethora of sources that should otherwise inform our sources of biblical interpretation. He posits that our unique black experience should be explored rather than western expressions and experiences that failed to address our life situations. The African experiences, culture, worldview, as well as interactions with the Word, should form the basis for our unique reception and interpretation. Omoyajowo (1973) notes that the primary reason for the formation of some African indigenous churches was the desire to break even from European domination. There is the desire to recognise and create a niche independent of western hegemony that speaks to the peoples' needs without "a middleman."

The primary rule of hermeneutics here should be premised on the utilization of the African sociocultural milieu void of western flavour as the basis for reception and interpretation and analysis of life experiences while adopting contextual application. Mbiti (1956) observes the uniqueness of Africans which under guides the daily interpretation of all phenomena. The literary interpretation of the text among Africans is closely akin to the Hebrew understanding. Hence, when the African says that the Lord is here, he writes and makes His presence felt through the manifestation of his power. God is not read in abstraction rather Africans see Him in everything they do within the culture. 


\section{Qualities for Engagement in Decolonization}

Adamo (2001) contends that certain qualities are needed which are fundamental. The Africanness of the individual plays a major role here. While some scholars may disagree with his opinion, the truth must be told without fear or favour. The early religious experience of our history was mostly documented by sit-at-home writers who never stepped their foot on the soil of the continent. Some of the accounts presented about the nature of African religions were lopsided, skewed towards hatred, jealousy, and above all, directed towards the destruction of the rich socio-cultural background of the people. Hence, the religion was ignorantly described as animistic, barbaric, and the people without the knowledge of God.

Good knowledge of the subject matter cannot be over-emphasised. Okoye (2015) stresses on the vital role of knowledge on the part of the teacher in ensuring that the intended outcome is achieved. In the task of decolonisation, the Bible is the curriculum, the only major requirement is a good working knowledge on the part of the interpreter. The contemporary challenge is that most of our scholars, materials/methods for instruction are potential tools of Western ideology. To avoid repetition and the danger of simply rebranding the subject, Kincheloe (2005) suggests critical pedagogy as a sure path to delivering the content as expected but not as usual. The usual expectation has not only damped and dashed the hope of the people but it has perpetrated the colonisation process even in the face of the present struggle against western hegemony in Biblical interpretation.

Understand the uniqueness of African culture as a requirement cannot be compromised. This is the bane of the poor representation of the rich religious experiences of the people in Africa. The distinctive qualities of any person lie in their culture. Hence E.B. Tylor (1832-1917) exhaustively understudy the phenomenon in his definition. He sees the complexity of culture as a nested triangle yet a continuum. Its elements thus include but not limited to knowledge, belief, art, law, morals, custom, and any other capabilities or habits that members would have acquired over time. It is a way of living in a particular community, the sum total of all things that refer to religion, roots of people, symbols, language, songs, stories, celebrations, clothing and dressing, and all expressions of our way of life.

Omoyajowo (2005) stresses on the place of culture in the early day of Christianity in Nigeria. He notes that the major reason why the missionaries failed in their first attempt in Christianising Nigeria was largely as a result of their failure to learn from the traditional religion of the people. Africans uniquely cannot be separated from their religion; a core pillar in everyday life. It further buttresses the argument motioned by Adamo (2001), why a stranger should not be admissible into the noble task of biblical interpretation in Africa. Okoye (2015) outlines the necessity of the subject matter that behoves the interpreter to demonstrate practical knowledge as well as good skill in memorisation of the Bible content sufficiently.

\section{Benefits of Biblical Decolonisation}

The followings are some derivable benefits of the process of decolonisation as a people within a nation.

- Springboard for appraising the status-quo of the ancient biblical tradition,

- Explore African understanding as a method of interpretation.

- It promotes the communal spirit inherent in Africa as the socio-cultural context is taken into consideration, Vernacular Hermeneutics, teaching, and homily build confidence and acceptability in the minds of the people.

- It provides the platform for addressing the lopsided approach to Christian theology that is void of liberation, otherwise acted as oppressive and anti-humans, counterproductive, and gospel.

\section{BACKGROUND OF NIGERIAN EDUCATIONAL SYSTEM}

By 1914, the colonialists have no definite plan and philosophy as to the future of Nigerian education (Itedjere, 2007). Two commissions are of importance here: Phelps-Stoke and Elliot. The Phelps-Stoke was one of the fledgling philanthropic organisations then in America that was started by Miss Caroline Phelps-Stokes in 1911 to raise 
religious and educational support for Blacks globally. The appeal came as a result of the perceived failure of the colonial government to support education in Nigeria and indeed Africa. The hue and cry of Africans thus attracted the sympathy of the American Baptist Foreign Missionary Society who has studied the situation, took the bull by the horn to approach the Caroline Phelps-Stokes foundation both to remedy and declare a state of emergency in the education and religion of Africans as to provide functional education relevant to the people in their local context. These commissions held the true accounts of the clamour for functional education in Africa, the envisioned education by Caroline Phelps-stokes aimed at decolonizing the educational system for Africans.

The major concern of the commission was to West Africa in 1920 and East and Central Africa in 1924 was lay declare the dysfunctional state of the missionary curriculum geared towards only cognitive development, to provide for the missionary needs for clerical officers hence, it advocated for the comprehensive and holistic education, meeting the needs of the people, even vocationally. To provide the people developmentoriented education that will salvage the local needs. The government, therefore, is saddled with the responsibility Government to organize and supervise both educational and religious (Fafunwa, 1974).

Omolewa, (2006) notes that by 1923, the recommendations were fully carried out with implementation modalities aimed at putting straight the records. This was immediately followed by the appointment of an advisory committee on native education in tropical areas they are saddled with the responsibility of reporting the progress of education in the British colonies. Elliot's commission reports (1943), thus became an answered prayer to the yearning and aspiration of the people. Provisions were made for the establishment of tertiary institutions namely: University Colleges in Nigeria, the Gold Coast (Ghana), and Sierra Leone. By 1969, The Nigerian elites at the National Assembly Hall at Lagos had already put in place the proposed functional education otherwise indigenous curriculum for the education of the people (Taiwo, 1980).

\section{Decolonisation of the Nigerian Educational System}

The present challenge bedevilling the nation is a function of colonial impoverishment and threats of globalization. Hence the need for the overhauling of the curriculum to provide sustainable growth opportunities for her citizenry; to incorporate and teach our history, culture, and indigenous epistemologies/knowledge system. Aderemi (2019) decries the impact of colonialism that has obstructed and short-changed African values. He notes that the people are alienated from their rich cultural heritage and indigenous epistemologies. However, the purpose of decolonization is aimed at selfrealization, the continuous task for present-day African scholarship.

We have to promote cultural base education for selfrediscovery and potential development among our people. The act of over-dependence on exotic culture should be discouraged especially now that the continent and indeed Nigerian is at a cross-road. The use of vernacular hermeneutics, teaching, storytelling should be encouraged. Adamo (2001) advocates for the collective reading of the Bible in vernacular language. The effort will not only help to build self-confidence in our youths. The dearth of local craft and technologies in the continent is premised on the quest for foreign material however, through a systematic synergy, our local language and technology can be enhanced. It will promote the development of the needed skill acquisition and vocational training centres that are need-oriented.

The people should make for greater investment in cultural arts, curatorship, and traditional artefacts. The impact of the colonialists in the destruction and removal of traditional artefacts cannot be overemphasised. Lime (2018) strongly accused the colonial rule of the massive plunder of thousands of cultural artefacts that were taken to various museums across the globe and especially Europe. The Benin Bronzes were taken away in 1879 , the Rosetta Stone of Egypt, the Bangwa Queen of Cameroon which is a wooden carven looted by the German named Gustav Conrau in 1899.

Ogbeche (2021) thus laments the thoughtless removal of history from the Nigerian educational system otherwise making it an elective course at the 
Basic level. The Minister of Education and the Education Committee failed to acknowledge the labour of our forbearers, whose work cannot be denied. History as a subject should be encouraged at all levels as it possesses the capacity to promote a sense of unity and cohesion. Otwin (1990) notes that the same philosophy remained the brain-child behind the establishment of the now troubled National Youth Service Corps (NYSC) in Nigeria that was established on 22 May, 1973 with the basic assumptions of reconciliation, rebuilding, and reorientation of her youths towards unity, social integration, and development

Promote a sense of national unity, brotherhood, and oneness, and build a sense of pride and belonging amidst globalization and its uncertainties. The recent xenophobic expression in South Africa against some non-nationals has not only to betray the continent but the people. The oneness of the people, the elements that binds the people should be strengthened as a bond. The principle of Ubuntu, Ekwevugbe with Oniovo is premised on brotherhood (Isiorhovoja, 2019). The worth of unity is best captioned in Genesis 11, the expression of one mind towards a project the remained indestructible if not for Divine intervention.

\section{Challenges of Decolonising Nigerian Educational System}

Scholars have raised vital questions about the Nigerian educational system. Some of which bothers on, 'where did we miss it?" Arguably, they have posited that the major reason why decolonization of the educational system has failed is due to acculturation. Lebeloane (2017) argues that acculturation has constituted a major threat to the decolonisation process that could impact on the loss of personal identity. Like the cancer worm, it has the ability of invading the people's culture which speaks volumes that is best imagined. Consequently, the learners stand the chance of systemic alienation through the impact of the curriculum.

The plethora of curriculum available to the nation has not only plundered our thought system but has kept us between the devil and the deep blue sea. Since the Phelps-Stoke and Elliots's commissions were made available to Nigeria, the nation has continuously jettison between one form of curriculum or the other. We have continuously experimented between models that seem to appeal to the minds of few individuals who seek personal pleasure than the maximum good of the populace. The Phelps-Stoke commission laid the path to speedy development, an indigenous system unique to the continent yet, our curriculum planners are chasing fantasies and comparing different models, leaping between opinions.

Self-submission to Western ideology as a global standard of excellence in education. From the traditional educational curriculum, the history which is an important part of human society should teach us the path to a balanced society. Amaele (2003) posits that we can rely on it because its information is reliable about places, people, and events of the past. Any recorded events are true live accounts; hence, it is a recreation of the true picture of events of the past for the present. While consciously alluding to Western culture and its fantasies, we have also unconsciously sold out our conscience and thought. Today, the best measure of scholarship is based on Western viewpoints, journal assessment and acceptability is based on Scopus standard, best expression is Western. Where then is the place of the Indigenous Knowledge System (IKS)?

Ashcroft et al. (2007) identify Western hegemony as a constraint to a new conversation on a possible local alternative. Most scholars of African origin have been faced with this problem. Adamo (2004) traces the root to the background of most scholars of African descent who have received their scholarship training from the West. They wish to maintain close ties with their Alma Mata, subject their thoughts and scholarship to the dictates of their masters, thereby condemning every other idea that appears to be a variant to what they have learned. Another reason for the hegemony is the poor scholarship and non-availability of support and published works by indigenous scholars. Apart from few privileged persons who have made it here in Africa, some have not made it a point of duty to document their thoughts for the future generation. It is worthy of note to say here that we readily break ties with our graduated students. The absence of fellowship and its essence is lost in the process of a broken relationship. Consequently, the few who 
dare to make it through to the end are kept in perpetual bond through fellowship and other special programmes that will ensure that they are kept close, consequently, we find undue loyalty to Western masters and curriculum all in a bid to gain acceptability and certification

Non-availability of indigenous curriculum models is the bane of this system. Fafunwa (1974) motions the following as the major propositions for traditional education. His contentions which actually serves as the enlargement of curriculum seeks to enhance skill development, character building, good societal moral, respect for authority and institutions, the dignity of labour and appreciation of the rich cultural heritage. These lofty points are well in tandem with the submission of the Phelps-Stoke commission. Lebeloane (2017) notes that poor governmental policies/funding of local content, research, and implementation are directly responsible for the failure of our system.

Inferiority ideology among Nigerian scholars in evolving a functional indigenous system and the fear of rejection has remained a juggernaut. The will to make progress as well as the motivation and sacrificed on the altar of fears of the unknown and the absence of the will to make a change. The frequent diffusion forms the third world to the first world is associated with the absence of love for one another and the nation. The frequent movement of scholars commonly referred to as brain-drain is the workings of our leaders who have failed to stick with the recommendations of local content development and utilisation.

\section{Accruable Benefits from Decolonization of Education}

- The Nigerian populace becomes the centre of the curriculum; hence its interpretation will be people-oriented.

- Following the recommendations of the PhelpsStoke's commission, personal and sustainable societal development becomes twin projects. The social environment remains friendly and inviting.

- It will provide the niche for interaction and evaluation of global trends that are otherwise inimical to our rich socio-cultural environment and system. Inculturation becomes the basis for adjudging what whatsoever we should accept as a people.

- Rapid development of the society that will promote good research and work environment which will check brain-drain syndrome and scholarly society that we can truly say is authentically African.

\section{CONCLUSION}

The present study is not aimed at condemning the efforts of the missionaries and colonialists rather, it seeks to address our present challenges that have remained a lacuna through the curriculum. The quest should be seen as a juggernaut aimed at rediscovering ourselves and moving towards sustainable development of the people and the environment.

Though many have expressed fears over the fate of the indigenous educational curriculum, but this should not deter us from embarking on the journey. There are ample chances of making good the system if only we employ the recommendations of PhelpsStoke's Commission as a model in our journey towards a better day for Nigeria. Hence, the call to believe in ourselves and develop the system with home-funding through our government and Nigerians in the diaspora; to revamp, restructure and redirect our efforts towards a functional indigenous system.

Nigerian educational scholars should mentor younger generations through systematic removal of the dysfunctional curriculum to create a better sense of belonging. The era of lone ranger should give way to the collective spirit of team-building commonly expressed in Ubuntu and Ekwevugbe. The principle of you is because I am, united we stand. The adoption of the right principle and its utilisation can only lead to the systematic dismantling of all forms of enforced slavery. However, we can make it through decolonisation.

Nigeria will become the melting pot if her leadership quickly recognize the need to necessities that helps to garnish the system. The people are hardworking just they are not opportune to showcase their wares due largely to poo environmental factors.

87 | This work is licensed under a Creative Commons Attribution 4.0 International License. 


\section{REFERENCE}

Achtemier, P. (ed) (1996). The harper Collins Bible dictionary. New York: Harper Collins.

Adamo, D. T. (1999). African Cultural Hermeneutics", in Vernacular Hermeneutics, edited by R.S. Sirgatharajah, Sheffield: University of Sheffield Press, 67-91.

Adamo, D. T. (2001). Reading and interpreting the Bible in African indigenous churches. Wipf and Stock Publishers.

Adamo, D. T. (2004). Africa and Africans in the New Testament. Oregon, USA: WIPF and Stock Publishers.

Aderemi, S. A.(ed) (2019). Indigenous epistemology, strengthening research and decolonization of Education in Nigeria. Ibadan African Ethnography series.

Amaele, S. A. (2003). A study guide on history and policy of education in Nigeria. Ilorin: INDEMAC.

Ashcroft, B. Griffiths, G. and Tiffin, H. (2007). Post-colonial studies the key concepts. New York: Taylor and Francis,

Bailey, R. C. (1991). Beyond identification: the use of Africans in Old Testament poetry and narratives. Stony the road we trod, 165-186.

Bromiley, G.W. (ed). (1979). Cush, Cushi, Cushan in the International Standard Bible Encyclopedia Vol. 1. Grand Rapids Michigan: WB Eerdsmans.

Cone, H.J. (1986). A black theology of liberation. Maryknoll: Orbis Books.

Dake, F. J. (1963). Dake's Annotated Reference Bible Dake Bible Sales. Inc., PO Box, 173.

Fafunwa, B. A. (1974). History of Education in Nigeria. London: Allen.

Gottwald, N. K (1985). The Hebrew Bible. A socioliterary introduction. Philadelphia: Fortress Press.
Heinrichs, S. (2019). Unsettling the Word: Biblical Experiments in Decolonization. Orbis Books.

Isiorhovoja, O. U. (2019). Pauline theology on gender issues: a continuity or disruption in Africa. Ubuntu: Journal of Conflict and Social Transformation, 8(Special Issue 2), 173-187.

Joy, D. (2012). Decolonizing the Bible, Church, and Jesus: A Search for an Alternate Reading Space for the Postcolonial Context. In Decolonizing the Body of Christ (pp. 3-24). Palgrave Macmillan, New York.

Kincheloe, L.J. (2005). Critical pedagogy. New York: Peter Lang.

Lebloane, L. D. M. (2017). Decolonizing the school curriculum for equity and social justice in South Africa. Koers, 82(3), 1-10.

Lime, A. (2018). A guide to Africa's looted treasures. https://www.bbc.com/news/worldafrica-45406557

Lokel, P. (2006). Previously unstoried lives: the case of Old Testament Cush and its relevance to Africa. Old Testament Essays, 19(2), 525-537.

Mbiti, J. S. (1975). Challenges of language, culture, and interpretation in translating the Greek New Testament" in Swedish Missiological Themes, 97, $2: 141-164$.

Ogbeche, E. (2021). Removal of history from the curriculum. The Abuja inquirer.

Okoye, N. S. (2007). Theory and practice of curriculum development. Abraka: University Printing Press.

Omoyajowo, J, A. (2005). Makers of the Church in Nigeria 1842-1947. Lagos CSS Bookshop Limited.

Otwn, M. (1990). Implementing deployment policies in the National Youth Service Corps of Nigeria: Goals and constraints. Comparative Political Studies, 22(4), 397-436.

Taiwo, C. O. (1980). The Nigerian education system, past, present and future. Thomas Nelson (Nigeria) Limited.

88 This work is licensed under a Creative Commons Attribution 4.0 International License. 
East African Journal of Traditions, Culture and Religion, Volume 3, Issue 2, 2021

Article DOI: https://doi.org/10.37284/eajtcr.3.2.426

Wahab, E. O., Odunsi, S. O., \& Ajiboye, O. E. (2012). Causes and consequences of rapid erosion of cultural values in a traditional African society. Journal of Anthropology, 2012.

89 This work is licensed under a Creative Commons Attribution 4.0 International License. 